\title{
Reducing Substrate Moisture Content (SMC) during Greenhouse Production and Postproduction of Angelonia and Heliotrope Improves Crop Quality and Economic Value
}

\author{
Yanjun Guo', Terri Starman, and Charles Hall \\ Department of Horticultural Sciences, Texas A\&M University, 2133 TAMU, \\ College Station, TX 77843
}

Additional index words. bedding plants, water stress, water, postharvest

\begin{abstract}
Retail environments are rarely optimal for ornamental plants, and wilting caused by water stress is a major cause of postproduction shrinkage. The objective of this study was to determine the effect of two levels of substrate moisture content (SMC) applied during greenhouse production on angelonia (Angelonia angustifolia) 'Angelface Blue' and heliotrope (Heliotropium arborescens) 'Simply Scentsational' growth and physiological parameters and subsequent postproduction quality during simulated retail conditions. At the end of production, angelonia total plant shoot dry weight (DW) was reduced with $20 \%$ SMC compared with $40 \%$ SMC, and plants grown with $20 \%$ SMC had higher shoot coloring percentage, reduced internode length, and required less irrigation labor-related costs compared with $40 \%$ SMC. Heliotrope grown at $20 \%$ SMC produced the same size plant as $40 \% \mathrm{SMC}$, but had a higher shoot coloring percentage at the end of production and postproduction, indicating lower SMC resulted in higher visual quality compared with $40 \%$ SMC. For both species, $20 \%$ SMC increased plant visual quality compared with $40 \%$ SMC and reduced irrigation water input throughout production, resulting in reduced production costs and increased floral crop economic value.
\end{abstract}

In 2013 , the U.S. green industry generated $\$ 136.44$ billion in direct output, of which $\$ 16.77$ billion were contributed by greenhouse and nursery growers (Hodges et al., 2015). To produce high-quality, uniform, and consistent products, commercial floriculture greenhouses and nurseries apply irrigation and fertilization at a high frequency, thus, potentially leading to the contamination of ground and surface water (Richards and Reed, 2004). Reducing volume or frequency of irrigation would not only save water, but could also reduce the greenhouse production time and costs by reducing water-related energy, labor, fertilizer, pesticides, growth regulators, and overhead costs, thus increasing sustainability (Lichtenberg et al., 2013). Also, studies show that plants with more sustainable attributes positively affect consumer preferences (Behe et al., 2013; Hall et al., 2010).

The portion of crops grown but considered unsalable is termed shrinkage. The later the shrinkage occurs in the value chain, the larger the impact it has on profitability because more inputs such as overhead, labor, water, fertilizer, and pesticides have been used before plants are thrown away. A recent survey of larger growers reported that

Received for publication 25 Jan. 2018. Accepted for publication 15 May 2018.

${ }^{1}$ Corresponding author. E-mail: cguo@tamu.edu. production level shrink ranged from $2 \%$ to $10 \%$, with a median of $5 \%$, whereas retaillevel shrink ranged from $8 \%$ to $33 \%$, with a median of $19 \%$ (Hall et al., 2011). Leaf and flower senescence and flower abscission induced by ethylene or water deficit during shipping and shelf life causes the plant to lose its esthetic value, another cause of postharvest shrinkage for bedding and potted plants (Starman et al., 2007). Inadequate irrigation is a major challenge during postproduction (shelf life) because irrigation systems are almost never ideal in retail environments because of untrained personnel or understaffing.

Nemali and van Iersel (2006) developed a sensor-based automatic irrigation system to reduce irrigation water usage by maintaining distinct and constant SMC levels throughout the production period. By controlling the timing and length of lower SMC level, a controlled water deficit was applied to potted floral plants. Using controlled water deficit irrigation during greenhouse production could not only reduce water input and increase plant water use efficiency (WUE), but also increase plant quality by producing a more compact plant without applying a plant growth regulator. Applying water at a consistent $20 \%$ SMC during greenhouse production of angelonia (A. angustifolia) 'Angelface Blue' produced a more compact crop because of shorter internodes, and reduced or prevented wilting during the water deficit postproduction period, thus increasing plant postproduction quality. This consistent water deficit throughout angelonia production also increased the WUE (Jacobson et al., 2015). Similar results were reported for poinsettia (Euphorbia pulcherrima). A constant $20 \%$ SMC was also an effective alternative shoot height control method compared with plant growth retardant (daminozide, BNine) application during poinsettia greenhouse production (Alem et al., 2015).

The objective of this study was to determine the effect of water deficit using two levels of SMC applied by the dry-down method during greenhouse production on angelonia and heliotrope growth and physiological parameters. The dry-down method used in this study was conducted by irrigating to container capacity (CC) when the target SMC level was indicated by the sensor reading. The root substrate was dried back down to the target SMC and re-watered to CC repeatedly as needed throughout the experiment. We also studied the effects on postproduction performance during simulated retail conditions. Lastly, we examined the effects on associated economic costs. Our hypothesis was that lower SMC during greenhouse production would lower irrigation costs, better acclimate plants for the retail environment, and allow plants to maintain higher quality during postproduction.

\section{Materials and Methods}

Plant material and growing conditions. Rooted cuttings of angelonia and heliotrope (H. arborescens) 'Simply Scentsational' were obtained from a commercial propagator (EuroAmerican Propagators, Bonsall, CA) during production week 4 (26 Jan. 2016) and graded for uniformity on arrival. One rooted cutting was planted in each of 403.79 L nursery containers (Nursery Supplies Inc., Kissimmee, FL) with commercial peat-based soilless root substrate ( $85 \%$ Canadian sphagnum moss and $15 \%$ perlite; BM 6, Berger, Saint-Modeste, Canada) with $17 \mathrm{~g}$ of $15 \mathrm{~N}$ 3.9P-9.9K slow release fertilizer per container (Osmocote, Peters Professional; Scotts-Sierra, Marysville, $\mathrm{OH}$ ) incorporated evenly throughout before planting. Plants were grown in a glass wall and polycarbonate roof greenhouse in College Station, TX, for the greenhouse production stage [from $11 \mathrm{Feb}$. (production week 6) to 17 Apr. (production week 16), 2016.]. Plants were treated with an etridiazole and thiophanate-methyl (Banrot; Everris NA Inc., Dublin, OH) root substrate drench to prevent root rot. Plants were then allowed $14 \mathrm{~d}$ for root establishment before initiation of irrigation treatments. During this time, they were watered once in addition to the Banrot drench.

The average temperature in the greenhouse during the experiment was $24.7{ }^{\circ} \mathrm{C}$ day $/ 19.7{ }^{\circ} \mathrm{C}$ night. Average daily light integral (DLI) was $23.43 \mathrm{~mol} \cdot \mathrm{m}^{-2} \cdot \mathrm{d}^{-1}$ and relative humidity was $56.2 \%$ during the greenhouse production stage of the experiment. Environmental data were measured by WatchDog 450 data loggers and LightScout 
quantum light sensors (Spectrum Technologies Inc., Aurora, IL).

At week 13 (1 Apr. 2016), plants were deemed to be marketable based on industry standards. At this time, plants went through a simulated shipping process. Simulated shipping consisted of hand-watering to $\mathrm{CC}$ before moving plants by cart into a dark laboratory for $48 \mathrm{~h}$ at $20 \pm 2{ }^{\circ} \mathrm{C}$ and $42.1 \%$ relative humidity. After shipping, plants were

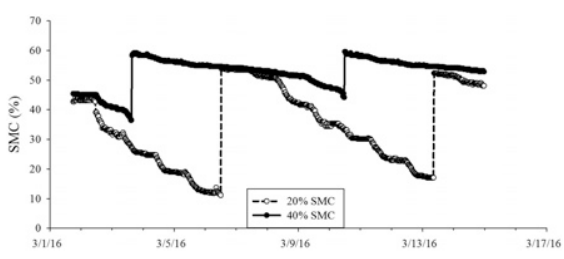

Fig. 1. Fourteen days (1-14 Mar. 2016) of 20\% and $40 \%$ substrate moisture content (SMC) treatment sensor readings during greenhouse production. The $20 \%$ and $40 \%$ SMC substrates were irrigated to container capacity when the target SMC levels were indicated on the sensors. SMC was calculated as SMC $=($ substrate wet weight - substrate dry weight $) \times 100 \% /$ 1000.
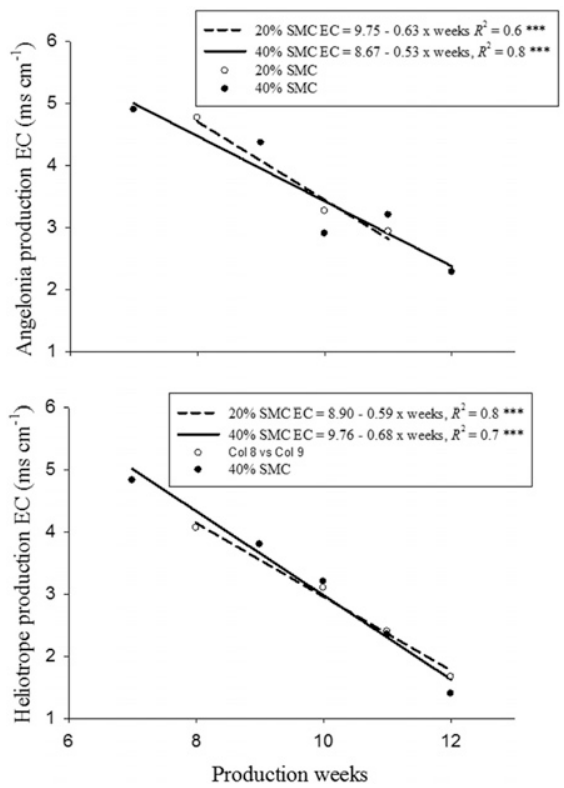

Fig. 2. Electrical conductivity (EC) of Angelonia angustifolia 'Angelface Blue' and Heliotropium arborescens 'Simply Scentsational' throughout the greenhouse production stage of the experiment (production weeks 6-13). *** indicates significance of the linear regression at $P \leq 0.001$. SMC $=$ substrate moisture content. returned to the greenhouse by cart and held under $50 \%$ shadecloth for 2 weeks (week 14 and 15) for simulated shelf life, during which plants were only watered when wilting began to occur. During the postproduction, the average temperature in the greenhouse during the experiment was $22.4{ }^{\circ} \mathrm{C}$ day $/ 19.8{ }^{\circ} \mathrm{C}$ night. Average DLI was $11.1 \mathrm{~mol} \cdot \mathrm{m}^{-2} \cdot \mathrm{d}^{-1}$ and relative humidity was $65.1 \%$.

Substrate moisture content treatments. Two irrigation treatments $(20 \%$ and $40 \%$ SMC) were applied in two experiments (one species per experiment) starting at production week 8 and ending at production week 13 (the greenhouse production stage). SMC was defined as $V_{w} / V_{T}\left(V_{w}\right.$ is the volume of water; $\mathrm{V}_{\mathrm{T}}$ is the total volume of substrate particles, water, and air space). The $40 \%$ SMC treatment (well-watered, traditional irrigation method) consisted of allowing the substrate to dry down to $40 \%$ SMC before handwatering to $\mathrm{CC}(59.6 \% \mathrm{SMC})$, which was until the initiation of drainage. The $20 \%$ SMC treatment (alternative irrigation method) consisted of allowing substrate to dry down to $20 \%$ SMC before hand-watering to CC. Substrate moisture contents were monitored by a watchdog 1000 series Micro Station, and SM 100 WaterScout soil moisture sensors (Spectrum Technologies, Inc., Aurora, IL). There was one sensor per treatment per species inserted in the root substrate of a container that was closer to the center of the greenhouse bench to reflect the average SMC of the treatment and avoid the drying effect of the bench edges. Sensors recorded SMC every $30 \mathrm{~min}$ and each irrigation event was determined based on the sensor readings (observed daily) and the calibration of the sensor (Fig. 1). All irrigations used reverse osmosis water.

Sensor calibration. Soil moisture sensors were calibrated by filling five 1-L plastic beakers with 1-L volume of oven dried root substrate. Substrate density was standardized by tapping dry substrate filled plastic beakers five times from a uniform height $\approx 3-6 \mathrm{~cm}$ above a sturdy table (Fonteno et al., 1995). Each beaker was emptied into one of five polyethylene plastic bags (Ziploc; S.C. Johnson \& Son, Inc., Racine, WI), and 100, 200, 300,400 , or $500 \mathrm{~mL}$ of water was poured into one of the five bags. Root substrate was mixed with the water thoroughly and allowed to incubate for $24 \mathrm{~h}$. All DW, wet weight (WW), and net weight of the beakers were measured and recorded. Root substrate was repacked into the same plastic beaker as before. Three sensor readings were taken at three different locations in the beaker, avoiding taking readings too close to the edge of the beaker according to the WaterScout SM 100 Soil Moisture Sensor Product Manual. Substrate moisture content was calculated as SMC = $(\mathrm{WW}-\mathrm{DW}) \times 100 \% / 1000$ (Cai et al., 2012).

Data collection. For the economic analysis of water usage, containers were weighted before each irrigation event during the production and postproduction stage of the experiments. After irrigation, containers were allowed to drain for $1 \mathrm{~h}$ and then reweighed. The weight difference was calculated and recorded to determine total irrigation volume. Each irrigation event was documented and summed to determine total number of irrigation events during production and/or postproduction.

Starting production week 6 , substrate leachate electrical conductivity (EC) and $\mathrm{pH}$ were monitored weekly for $40 \%$ SMC, and measured after each irrigation event for $20 \%$ SMC using the pour-thru method (LeBude and Bilderback, 2009; Wright, 1986), with a LAQUAtwin EC22 Meter and a LAQUAtwin $\mathrm{pH} 22$ Meter (Spectrum Technologies Inc.). The $\mathrm{pH}$ for both angelonia and heliotrope was 6.0 at the beginning of the experiment and 5.5 at the end of the experiment. For both angelonia and heliotrope, EC decreased as the experiment proceeded and was unaffected by the SMC treatment (Fig. 2).

Plant height and width were recorded weekly. Plant height was measured from the root substrate surface to the plant growing point. Two plant widths were measured across the greatest plant width and the perpendicular width. Growth index (GI) was calculated as $\mathrm{GI}=$ plant height $/ 2+$ (plant width $1+$ plant width 2)/4 (Niu et al., 2007).

At the end of postproduction, all 10 replications for both species were destructively harvested. Data taken on angelonia at the end of postproduction included flower and bud number/stem on three major stems on each plant, total plant shoot DW, and total raceme number. Angelonia stems were divided into three sections: vegetative, flower, and bud. The length and node numbers of the three sections of the stem were measured, and internode length was calculated as length divided by node number. Flowers were those with the reproductive organs visible and buds were those not fully revealing the reproductive organs. Data taken on heliotrope at the end of postproduction included total flower number, cyme number, and total plant shoot DW. Total plant shoot DW was determined after being oven-dried at $80{ }^{\circ} \mathrm{C}$ for $48 \mathrm{~h}$ to constant weights.

To quantify the quality of plants, photos of shoots for both species were taken from

Table 1. The effect of substrate moisture content (SMC) on total plant shoot dry weight (DW), total raceme number, total stem length, bud stem node number, vegetative stem internode length, and flower stem internode length at the end of the postproduction (week 15) of Angelonia angustifolia 'Angelface Blue'. Substrate moisture content was calculated as $\mathrm{SMC}=($ substrate wet weight - substrate $\mathrm{DW}) \times 100 \% / 1000$.

\begin{tabular}{|c|c|c|c|c|c|c|}
\hline SMC (\%) & $\begin{array}{c}\text { Total plant } \\
\text { shoot DW }(\mathrm{g})\end{array}$ & $\begin{array}{l}\text { Total raceme } \\
\text { number }\end{array}$ & $\begin{array}{l}\text { Total stem } \\
\text { length }(\mathrm{cm})\end{array}$ & $\begin{array}{c}\text { Bud stem } \\
\text { node number }\end{array}$ & $\begin{array}{c}\text { Vegetative stem } \\
\text { internode length }(\mathrm{cm})\end{array}$ & $\begin{array}{c}\text { Flower stem } \\
\text { internode length }(\mathrm{cm})\end{array}$ \\
\hline$\overline{20}$ & $15.62 b^{z}$ & $11.0 \mathrm{~b}$ & $57.3 \mathrm{~b}$ & $5.1 \mathrm{~b}$ & $11.8 \mathrm{~b}$ & $1.9 \mathrm{~b}$ \\
\hline 40 & $19.06 \mathrm{a}$ & $12.7 \mathrm{a}$ & $60.4 \mathrm{a}$ & $6.0 \mathrm{a}$ & $13.2 \mathrm{a}$ & $2.0 \mathrm{a}$ \\
\hline
\end{tabular}

${ }^{\mathrm{z}}$ Means separation by Student's $t$ test, multiple comparisons at $P \leq 0.05$. 
above at the end of production and postproduction to determine the shoot coloring percentage (the percentage of the shoot covered by flowers). To determine how SMC affected root orientation in the container, root ball photos were taken at the end of postproduction from the bottom of the root ball and both sides of the root ball. Root ball covering percentage was the percentage of the substrate surface covered by roots after removal from the container. The shoot coloring percentage and root ball coverage percentage were analyzed with Photoshop CS6 (Adobe Systems Inc., San Jose, CA). Photoshop quantified the colored area (flowers) and green area (leaves), and the

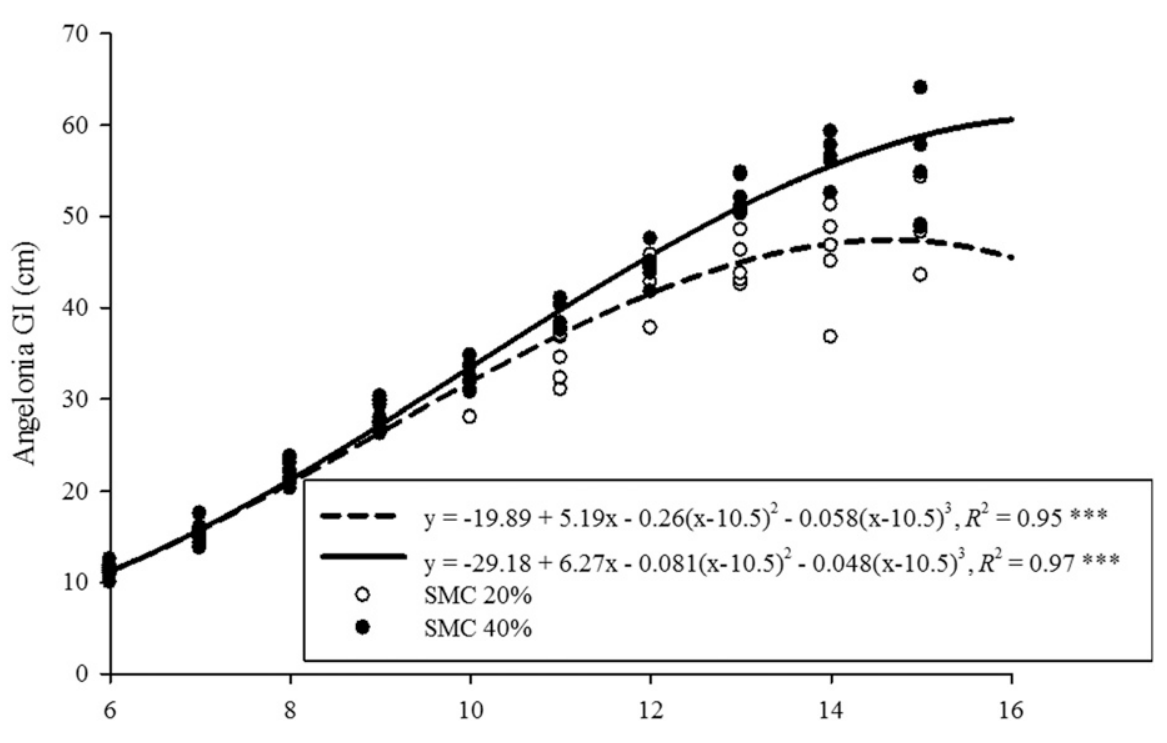

Production weeks

Fig. 3. Effect of $20 \%$ and $40 \%$ substrate moisture content (SMC) on weekly growth index [GI = plant height $/ 2+$ (plant width $1+$ plant width 2 )/4] from production week 6-13, and postproduction from week 14-15 of Angelonia angustifolia 'Angelface Blue'. SMC was calculated as SMC $=$ (substrate wet weight - substrate dry weight $) \times 100 \% / 1000$. *** indicates significance of the cubic regression at $P \leq$ 0.001 . total shoot area was calculated as colored area + green area. The shoot coloring percentage was then calculated as colored area divided by total shoot area. To determine root ball coverage percentage Photoshop quantified the total root ball area as root area + substrate area. The root ball coverage percentage was calculated as root coverage area divided by total area.

The relative greenness of leaves was measured by using a chlorophyll meter (Special Products Analysis Division; SPAD-502 Minolta Camera Co., Osaka, Japan) starting in week 10. SPAD readings of three fully expanded green leaves per plant were taken from three plants of each treatment. SPAD readings ranged from 0 to 100 by measuring the light transmission at wavelengths of 650 and $940 \mathrm{~nm}$ (Markwell et al., 1995).

Experimental design and data analysis. The experiment was a randomized complete design with 10 replications and two treatments $(20 \%$ and $40 \%$ SMC). Each species was analyzed separately. The data were analyzed by using SAS (version 9.4; SAS Institute, Cary, NC). Mean separation was conducted using student $t$ tests, if significant at the $5 \%$ level. The EC and GI were plotted against production weeks and linear or cubic regression was conducted and the significance was analyzed using JMP (SAS Institute).

Economic analysis. Partial budget modeling procedures were used to measure the costs and potential benefits of short-run changes in cultural practices in the production systems analyzed. For both tested plants, estimated container number per bench was calculated based on an industry standard bench size $\left(19.5^{\prime} \times 5.5^{\prime}\right)$ and the finished plant width. Space saved was calculated based on final spacing difference between the alternative irrigation method ( $20 \% \mathrm{SMC})$ and the traditional irrigation method $(40 \%$ SMC). Labor saved was calculated based on the difference in the number of irrigation events between the alternative irrigation method and the traditional irrigation method. Total water input was documented during each irrigation event. Irrigation amount saved was calculated based on the difference between total irrigation applied during the alternative irrigation method and the traditional irrigation method.

\section{Results and Discussion}

Plant morphology. At the end of postproduction (production week 15), there was no difference between SMC treatments for angelonia flower or bud stem lengths, vegetative or flower stem node numbers, flower or

Table 2. Cost of Angelonia angustifolia 'Angelface Blue' grown at two substrate moisture contents (SMCs) (20\% and $40 \%)$ in greenhouse production and postproduction.

\begin{tabular}{|c|c|c|c|c|c|c|}
\hline \multicolumn{7}{|c|}{ Production } \\
\hline SMC $(\%)$ & $\begin{array}{c}\text { Estimated } \\
\text { container } \\
\text { number/bench }\end{array}$ & $\begin{array}{c}\text { Space saved } \\
(\%)\end{array}$ & $\begin{array}{l}\text { Total no. of } \\
\text { irrigation events }\end{array}$ & $\begin{array}{c}\text { Labor saved } \\
(\%)\end{array}$ & $\begin{array}{l}\text { Irrigation amount } \\
\text { (L/pot) }\end{array}$ & $\begin{array}{l}\text { Irrigation amount } \\
\text { saved (\%) }\end{array}$ \\
\hline 40.0 & 70.0 & 0.0 & $8.0 \mathrm{a}$ & 0.0 & $7.8 \mathrm{a}$ & 0.0 \\
\hline \multicolumn{7}{|c|}{ Postproduction } \\
\hline SMC (\%) & $\begin{array}{c}\text { Estimated } \\
\text { container } \\
\text { number/bench }\end{array}$ & $\begin{array}{c}\text { Space saved } \\
(\%)\end{array}$ & $\begin{array}{l}\text { Total no. of } \\
\text { irrigation events }\end{array}$ & $\begin{array}{c}\text { Labor saved } \\
(\%)\end{array}$ & $\begin{array}{l}\text { Irrigation amount } \\
\text { (L/pot) }\end{array}$ & $\begin{array}{c}\text { Irrigation amount } \\
\text { saved (\%) }\end{array}$ \\
\hline$\overline{20.0}$ & 45.0 & 20.6 & $2.0 \mathrm{a}$ & 0.0 & $2.3 \mathrm{~b}$ & 8.8 \\
\hline 40.0 & 36.0 & 0.0 & $2.0 \mathrm{a}$ & 0.0 & $2.5 \mathrm{a}$ & 0.0 \\
\hline
\end{tabular}

${ }^{\mathrm{z}}$ Estimated container number/bench was calculated as standard bench size $\left(19.5^{\prime} \times 5.5^{\prime}\right) /$ average canopy size of the plant

${ }^{\mathrm{y}}$ Space saved was calculated based on final spacing difference between the alternative irrigation method $20 \%$ SMC and the traditional irrigation method $40 \%$ SMC.

${ }^{\mathrm{x}}$ Total no. of irrigation events during 8 weeks of greenhouse production.

${ }^{\text {w}}$ Means separation by Student's $t$ test multiple comparisons at $P \leq 0.05$. Means with the same letter are not different.

${ }^{\mathrm{v}}$ Labor saved was calculated based on irrigation events number difference between the alternative irrigation method (20\% SMC) and the traditional irrigation method (40\% SMC).

${ }^{\mathrm{u}}$ Total irrigation amount per container was the sum of each irrigation water input during 8 weeks of greenhouse production.

${ }^{t}$ Irrigation amount saved was calculated based on total irrigation amount difference between the alternative irrigation method (20\% SMC) and the traditional irrigation method ( $40 \% \mathrm{SMC})$. 
Table 3. Cost of Heliotropium arborescens 'Simply Scentsational' grown at two substrate moisture contents (SMCs) (20\% and $40 \%)$ in greenhouse production and postproduction.

\begin{tabular}{|c|c|c|c|c|c|c|}
\hline \multicolumn{7}{|c|}{ Production } \\
\hline $\mathrm{SMC}(\%)$ & $\begin{array}{c}\text { Estimated } \\
\text { container } \\
\text { number/bench }\end{array}$ & $\begin{array}{c}\text { Space saved } \\
(\%)\end{array}$ & $\begin{array}{c}\text { Total no. of } \\
\text { irrigation events }\end{array}$ & $\begin{array}{c}\text { Labor saved } \\
(\%)\end{array}$ & $\begin{array}{c}\text { Irrigation amount } \\
(\mathrm{L} / \mathrm{pot})\end{array}$ & $\begin{array}{c}\text { Irrigation amount } \\
\text { saved (\%) }\end{array}$ \\
\hline 20.0 & $56.0^{\mathrm{z}}$ & $2.8^{y}$ & $6.0^{\mathrm{x}} \mathrm{b}^{\mathrm{w}}$ & $25.0^{\mathrm{v}}$ & $7.5^{\mathrm{u}} \mathrm{b}$ & $5.3^{\mathrm{t}}$ \\
\hline \multicolumn{7}{|c|}{ Postproduction } \\
\hline SMC(\%) & $\begin{array}{c}\text { Estimated } \\
\text { container } \\
\text { number/bench }\end{array}$ & $\begin{array}{c}\text { Space saved } \\
(\%)\end{array}$ & $\begin{array}{c}\text { Total no. of } \\
\text { irrigation events }\end{array}$ & $\begin{array}{c}\text { Labor saved } \\
(\%)\end{array}$ & $\begin{array}{c}\text { Irrigation amount } \\
(\mathrm{L} / \mathrm{pot})\end{array}$ & $\begin{array}{l}\text { Irrigation amount } \\
\text { saved (\%) }\end{array}$ \\
\hline 20.0 & 31.0 & -12.0 & $2.0 \mathrm{a}$ & 0.0 & $1.19 \mathrm{a}$ & 3.5 \\
\hline 40.0 & 35.0 & 0.0 & $2.0 \mathrm{a}$ & 0.0 & $1.23 \mathrm{a}$ & 0.0 \\
\hline
\end{tabular}

${ }^{\mathrm{z}}$ Estimated container number/bench was calculated as standard bench size $\left(19.5^{\prime} \times 5.5^{\prime}\right) /$ average canopy size of the plant.

${ }^{\mathrm{y}}$ Space saved is calculated based on final spacing difference between the alternative irrigation method $20 \% \mathrm{SMC}$ and the traditional irrigation method $40 \%$ SMC.

${ }^{\mathrm{x}}$ Total no. of irrigation events during 8 weeks of greenhouse production.

${ }^{\text {w}}$ Means separation by Student's $t$ test multiple comparisons at $P \leq 0.05$. Means with the same letter are not different.

${ }^{v}$ Labor saved is calculated based on irrigation events number difference between the alternative irrigation method (20\% SMC) and the traditional irrigation method (40\% SMC).

${ }^{\mathrm{u}}$ Total irrigation amount per container was the sum of each irrigation water input during 7 weeks of greenhouse production.

tIrrigation amount saved is calculated based on total irrigation amount difference between the alternative irrigation method (20\% SMC) and the traditional irrigation method (40\% SMC).

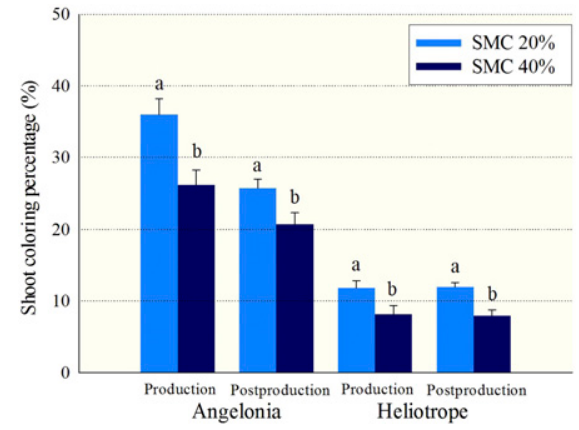

Fig. 4. The shoot coloring percentage of Angelonia angustifolia 'Angelface Blue' and Heliotropium arborescens 'Simply Scentsational' at the end of production (week 13) and the end of postproduction (week 15). Values obtained through Photoshop image process. Mean separation for both production times was obtained by using Student's $t$ test multiple comparisons at $P \leq 0.05$. Means with the same letter are not different. Substrate moisture content $(\mathrm{SMC})$ was calculated as $\mathrm{SMC}=($ substrate wet weight - substrate dry weight) $\times$ $100 \% / 1000$.

bud number per stem, total flower or bud numbers, or bud stem internode length (data not shown). Substrate moisture content at $40 \%$ increased total plant shoot DW, total raceme number, total stem length, bud stem node number, and vegetative and flower stem internode lengths (Table 1). Angelonia GI was greater with $40 \%$ SMC 1 week after SMC treatment began (week 9) and continued to be greater throughout production and postproduction (Fig. 3).

For heliotrope, there was no difference between SMC treatments for cyme number, shoot DW, or GI; only flower number differed between SMC treatments (data not shown). At the end of production, all heliotrope had 22 cymes $(\mathrm{SD}=1.9)$. Total flower number was greater with $20 \%$ SMC (567 flowers, $\mathrm{SD}=38.6)$ compared with 40\% SMC (389 flowers, SD = 40.9), which indicated that an average cyme was larger with $20 \%$ SMC than with $40 \%$ SMC, improving the visual quality of $20 \%$ SMC plants. Heliotrope GI was not different between SMC treatments at the end of greenhouse production $(39.3 \mathrm{~cm}, \mathrm{SD}=1.5 \mathrm{~cm}$, week 13) or postproduction $(44.2 \mathrm{~cm}, \mathrm{SD}=$ $1.3 \mathrm{~cm}$, week 15). At the end of postproduction (week 15), shoot DW was unaffected by SMC treatments $(31.3 \mathrm{~g}, \mathrm{SD}=0.9 \mathrm{~g})$.

The reduction in final GI (Fig. 3) and DW for angelonia was due to reduced internode length in the vegetative and flower stem sections. Reduced internode length has been associated with the inhibition of cell expansion during water deficit (Taiz et al., 2015). When water was deficient, shoot osmotic adjustment occurred slowly, cell wall loosening ability did not change, and the meristem was hydraulically isolated from the vascular system. When high evaporative demand exposed leaves to further water potential reduction, plant shoots became more sensitive and less favored to growth under water stress (Hsiao and $\mathrm{Xu}, 2000$ ).

Other studies have documented varying species response to reduced irrigation volume. Poinsettia (E. pulcherrima), crimson bottlebrush (Callistemon citrinus), hibiscus (Hibiscus acetosella), gardenia (Gardenia jasminoides), english lavender (Lavandula angustifolia), fan flower (Scaevola aemula), geranium (Pelargonium zonale), impatiens (Impatiens walleriana), oleander (Nerium oleander L.), big bend bluebonnet (Lupinus havardii), dusty miller (Cineraria maritima), petunia (Petunia $\times$ hybrida), and plumbago (Plumbago auriculata) were reported to have lower GI and DW when irrigation volume was reduced (Alem et al., 2013, 2015; Álvarez et al., 2011; Andersson, 2000; Bayer et al., 2013, 2015; Chyliński et al., 2007; Niu et al., 2006, 2007, 2008; Starman and Lombardini, 2006). However, the morphology of lantana (Lantana camara), cardinal flower (Lobelia cardinalis), geranium (Pelargonium hortorum), agastache (Agastache urticifolia), ornamental pepper (Capsicum annuum), and vinca (Catharanthus roseus) were unaffected by reducing irrigation volume (Chyliński et al., 2007; Niu et al., 2006; Starman and Lombardini, 2006).

Different responses of plants to controlled water deficit in studies reported in the literature could be due to different experimental methods or the anatomical and morphological variation among different plant species. Studies indicated that prolonged exposure to severe water deficit reduced plant growth, whereas short periods of moderate water deficit did not affect plant growth (Jacobson et al., 2015; Niu et al., 2006). When geraniums were kept at $30 \% \mathrm{SMC}$ for $10 \mathrm{~d}$, there was no significant effect on plant growth (Chyliński et al., 2007). In another study, reduced irrigation during geranium's entire production cycle showed significant growth inhibition (Andersson, 2000). Various results of water deficit effects may be due to species specific leaf morphology including leaf size, cuticle thickness, leaf surface texture, or number and structure of trichomes, which all affect transportation rate (Taiz et al., 2015). The different response to water deficit between species in this study may be due to the dense short hairs on both sides of heliotrope leaf surfaces (Cormier et al., 2011; Sakazaki, 2011) forming a thicker boundary layer, thus reducing transpiration under water deficit situations. Leaf hairs, formed by trichome cells, reduce transpiration water loss by covering the stomata crypts and increasing moisture in the boundary layer of the leaf surface (Begg, 1980; Monneveux and Belhassen, 1996).

Water usage and economics. In this study, we considered the $40 \%$ SMC treatment as the traditional well-irrigated method that is currently used by floral industry growers. Compared with angelonia grown under $40 \%$ SMC, plants grown under 20\% SMC have a smaller canopy; thus, they required less bench space, which may translate to lower overhead costs associated with bench space. 


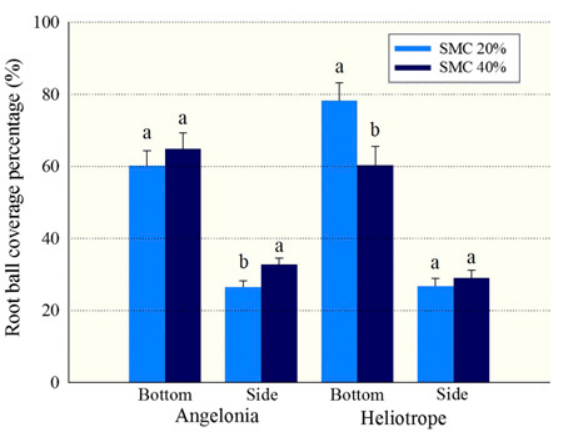

Fig. 5. The effect of $20 \%$ and $40 \%$ substrate moisture content (SMC) on root ball covering percentage, on the bottom and the average of two sides of the root balls after removal from the container for Angelonia angustifolia 'Angelface Blue' and Heliotropium arborescens 'Simply Scentsational'. Values obtained through Photoshop image process. Mean separation within the group was obtained by using Student's $t$ test multiple comparisons at $P \leq$ 0.05 . Means with the same letter are not different. SMC was calculated as SMC $=$ (substrate wet weight - substrate dry weight) $\times$ $100 \% / 1000$.

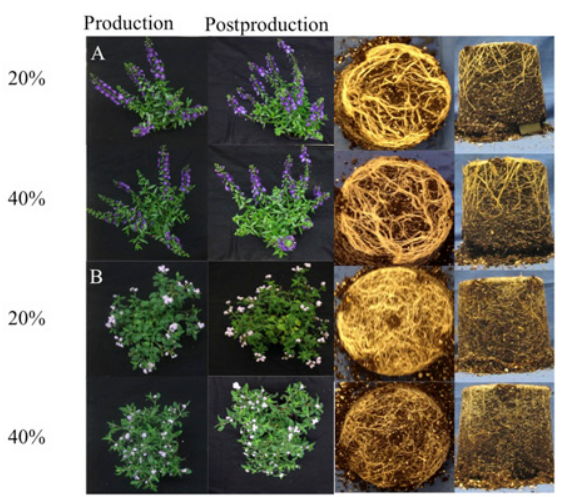

Fig. 6. Illustration of shoot coloring percentage and root ball coverage percentage for (A) Angelonia angustifolia 'Angelface Blue' and (B) Heliotropium arborescens 'Simply Scentsational' at the end of postproduction. SMC was calculated as $\mathrm{SMC}=($ substrate wet weight substrate dry weight) $\times 100 \% / 1000$.

Compared with $40 \%$ SMC, angelonia grown under $20 \%$ SMC saved $9.0 \%$ and $20.6 \%$ space during production or postproduction (Table 2), respectively. During production, $20 \%$ SMC required less irrigation; thus, angelonia saved $25.0 \%$ in irrigation laborrelated costs during production. However, postproduction irrigation event was unaffected by SMC treatment. Compared with $40 \%$ SMC, $20 \%$ SMC saved $16.3 \%$ and $8.8 \%$ irrigation amount during production or postproduction (Table 2 ), respectively.

Heliotrope canopy size was unaffected by SMC treatment during production; thus, the overhead-related savings was only $2.8 \%$ during production and even a negative $12 \%$ during postproduction. During production, $20 \%$ SMC saved $25 \%$ in labor but was unaffected by SMC treatment during postproduction.
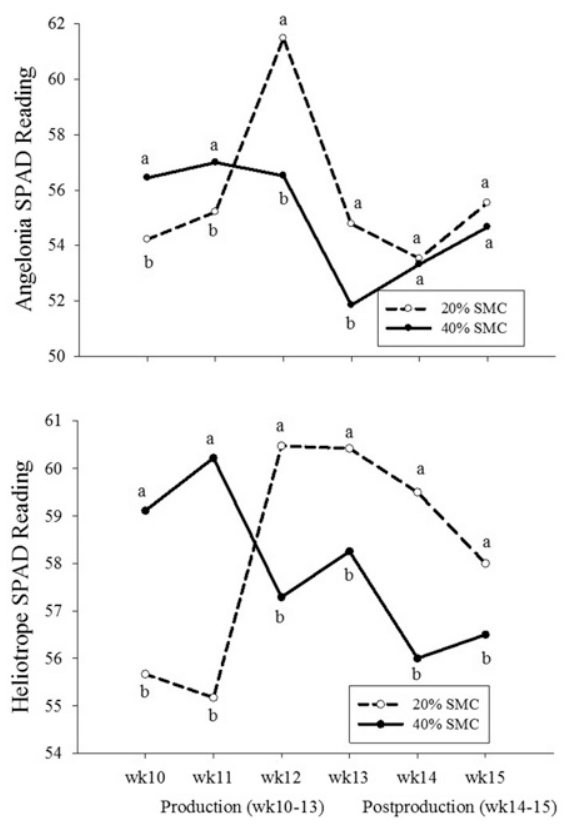

Fig. 7. Leaf chlorophyll index [Special Products Analysis Division (SPAD) values] for two soil moisture content (SMC) treatments for Angelonia angustifolia 'Angelface Blue' and Heliotropium arborescens 'Simply Scentsational' during greenhouse production from week 10 to 15 and postproduction from week 14-15. Means separation was obtained by using Student's $t$ test multiple comparisons at $P \leq 0.05$. Means with the same letter are not different. SMC was calculated as SMC $=($ substrate wet weight - substrate dry weight $) \times 100 \% / 1000$.

Compared with 40\% SMC, $20 \%$ SMC saved $5.3 \%$ and $3.5 \%$ irrigation amount during heliotrope production and postproduction (Table 3), respectively.

These results show that the costs of production were reduced by using an alternative watering method ( $20 \%$ SMC) compared with the traditional irrigation method (40\% SMC). The reduction in costs are a result of reduced bench space required (which reduced the residency cost or overhead costs), reduction of total irrigation water applied, and the irrigation labor-related costs (e.g., checking emitters).

Visual quality. Shoot coloring percentage was greater for both species with $20 \%$ SMC at the end of production and postproduction (Fig. 4). For angelonia, shoot coloring percentage was $36.0 \%$ or $26.1 \%$ during production and $25.7 \%$ or $20.7 \%$ during postproduction, for $20 \%$ or $40 \%$ SMC, respectively. For heliotrope, shoot coloring percentage was $11.8 \%$ or $8.2 \%$ during production and $11.9 \%$ or $8.0 \%$ during postproduction, for $20 \%$ or $40 \%$ SMC, respectively. For heliotrope, the $20 \%$ SMC produced plants with higher shoot color percentage by increasing the number of flowers in a cyme, resulting in increased cyme size. Shoot color percentage declined during postproduction for angelonia, but not for heliotrope. Root ball covering percentage also varied with species. Angelonia had fewer roots at the side of the container but not at the bottom of the container with $20 \%$ SMC compared with $40 \%$ SMC. Heliotrope had more roots at the bottom of the container but not at the sides of the container with $20 \%$ SMC compared with $40 \%$ SMC (Figs. 5 and 6).

For angelonia and heliotrope, in the first 2 weeks of treatment (week 10-11), 40\% SMC had higher SPAD; however, 3 weeks after starting SMC treatment, 20\% SMC had higher leaf chlorophyll index throughout the production stage. During postproduction, SPAD readings were not different for angelonia, but for heliotrope, the 20\% SMC still had higher SPAD readings compared with $40 \%$ SMC (Fig. 7). The higher SPAD reading for $20 \%$ SMC in angelonia and heliotrope could have been because of increased leaf thickness, lower leaf water content, or increased leaf chlorophyll content (Martínez and Guiamet, 2004). SPAD readings provided a quick, nondestructive, and objective estimation of visual quality of plant foliage (Wang et al., 2005).

\section{Conclusions}

Angelonia shoot and root growth were reduced with $20 \%$ SMC compared with $40 \%$ SMC, manifested as reduced total shoot DW and lower root ball coverage percentage on the sides of the pot. The visual quality of $20 \%$ SMC was higher at the end of production and postproduction, as shown by the higher shoot coloring percentage and shorter internode length, compared with $40 \%$ SMC. In short, $20 \%$ SMC produced more compact angelonia plants with increased visual quality.

Heliotrope morphological and physiological responses to SMC treatments were in contrast to those of angelonia. Shoot growth was unaffected by SMC treatment and there was greater root ball coverage percentage on the bottom of the container with $20 \%$ SMC. Heliotrope grown at 20\% SMC had higher shoot coloring percentage at the end of production and postproduction compared with $40 \%$ SMC, indicating that lower SMC resulted in higher visual quality. Therefore, $20 \%$ SMC produced the same size heliotrope with more potential for a higher survival rate and a better visual quality compared with $40 \%$ SMC.

The 20\% SMC reduced total irrigation event number and associated costs for both angelonia and heliotrope during production. Angelonia responded to $20 \%$ SMC with reduced plant canopy size compared with $40 \%$ SMC, thus reducing the bench space needed, thereby reducing the overhead costs incurred during greenhouse production. Based on partial budget modeling procedures we used in this experiment, $20 \%$ SMC proved to be a more cost-efficient production method for angelonia and heliotrope greenhouse growers. Further studies should be conducted to explore how other plant species respond to reduced SMC and their impact on economic value.

\section{Literature Cited}

Alem, P., P. Thomas, and M. van Iersel. 2013. Irrigation volume and fertilizer concentration effects on leaching and growth of petunia. Acta Hort. 1034:143-148.

Alem, P., P.A. Thomas, and M.W. van Iersel. 2015. Controlled water deficit as an alternative to 
plant growth retardants for regulation of poinsettia stem elongation. HortScience 50:565-569.

Álvarez, S., A. Navarro, E. Nicolás, and M.J. Sánchez-Blanco. 2011. Transpiration, photosynthetic responses, tissue water relations and dry mass partitioning in Callistemon plants during drought conditions. Scientia Hort. 129:306-312.

Andersson, N.E. 2000. Weight controlled irrigation of potted plants. Acta Hort. 559:371-375.

Bayer, A., I. Mahbub, M. Chappell, J. Ruter, and M.W. van Iersel. 2013. Water use and growth of Hibiscus acetosella 'Panama Red' grown with a soil moisture sensor-controlled irrigation system. HortScience 48:980-987.

Bayer, A., J. Ruter, and M.W. van Iersel. 2015. Automated irrigation control for improved growth and quality of Gardenia jasminoides 'Radicans' and 'August Beauty'. HortScience 50:78-84.

Begg, J. 1980. Morphological adaptations to water stress, p. 33-42. In: N.C. Turner and P.J. Kramer (eds.). Adaptation of plants to water and high temperature stress. Wiley Interscience, New York, NY.

Behe, B.K., B.L. Campbell, C.R. Hall, H. Khachatryan, J.H. Dennis, and C. Yue. 2013. Consumer preferences for local and sustainable plant production characteristics. HortScience 48:200-208.

Cai, X., T. Starman, G. Niu, C. Hall, and L. Lombardini. 2012. Response of selected garden roses to drought stress. HortScience 47:10501055.

Chyliński, W.K., A.J. Lukaszewska, and K. Kutnik. 2007. Drought response of two bedding plants. Acta Physiol. Plant. 29:399-406.

Cormier, M., E. Prentice-Hudson, C. Irving, S. Marcshall, M. Burvill, A. Balchin, J. Laplante, T. Henri, and G. Brecker. 2011. Plant varieties journal. Can. Food Inspection Agency. 18 Mar. 2018. <http://publications.gc.ca/collections/ collection_2011/inspection/A27-13-78-eng.pdf >.

Fonteno, W., C. Hardin, and J. Brewster. 1995. Procedures for determining physical properties of horticultural substrates using the NCSU porometer. Hort. Substrates Lab., N.C. State Univ., Raleigh, NC.

Hall, C., M.L. Jones, T. Starman, C. Pasian, and G. Staby. 2011. Shrink the shrink. Greenhouse Mgt. 18 Mar. 2018. <http://www.greenhousemag. com/article/greenhouse-0111-shrink/>.

Hall, C.R., B.L. Campbell, B.K. Behe, C. Yue, R.G. Lopez, and J.H. Dennis. 2010. The appeal of biodegradable packaging to floral consumers. HortScience 45:583-591.

Hodges, A.W., C.R. Hall, M.A. Palma, and H. Khachatryan. 2015. Economic contributions of the green industry in the United States in 2013. HortTechnology 25:805-814.

Hsiao, T.C. and L.K. Xu. 2000. Sensitivity of growth of roots versus leaves to water stress: Biophysical analysis and relation to water transport. J. Expt. Bot. 51:1595-1616.

Jacobson, A.B., T.W. Starman, and L. Lombardini. 2015. Substrate moisture content effects on growth and shelf life of Angelonia angustifolia. HortScience 50:272-278.

LeBude, V.A. and E.T. Bilderback. 2009. The pour-through extraction method: A nutrient management tool for nursery crops. N.C. State Univ. Coop. Ext. Bul. AG-717-W.

Lichtenberg, E., J. Majsztrik, and M. Saavoss. 2013. Profitability of sensor-based irrigation in greenhouse and nursery crops. HortTechnology 23:770-774.

Markwell, J., J.C. Osterman, and J.L. Mitchell. 1995. Calibration of the Minolta SPAD-502 leaf chlorophyll meter. Photosynth. Res. 46:467-472.

Martínez, D. and J. Guiamet. 2004. Distortion of the SPAD 502 chlorophyll meter readings by changes in irradiance and leaf water status. Agronomie 24:41-46.

Monneveux, P. and E. Belhassen. 1996. The diversity of drought adaptation in the wild, p. 714. In: E. Belhassen (ed.). Drought tolerance in higher plants: Genetical, physiological and molecular biological analysis. Springer, Dordrecht, The Netherlands.

Nemali, K.S. and M.W. van Iersel. 2006. An automated system for controlling drought stress and irrigation in potted plants. Scientia Hort. 110:292-297.

Niu, G., D.S. Rodriguez, and W. Mackay. 2008. Growth and physiological responses to drought stress in four oleander clones. J. Amer. Soc. Hort. Sci. 133:188-196.

Niu, G., D.S. Rodriguez, L. Rodriguez, and W. Mackay. 2007. Effect of water stress on growth and flower yield of big bend bluebonnet. HortTechnology 17:557-560.

Niu, G., D.S. Rodriguez, and Y.T. Wang. 2006. Impact of drought and temperature on growth and leaf gas exchange of six bedding plant species under greenhouse conditions. HortScience 41:1408-1411.

Richards, D.L. and D.W. Reed. 2004. New Guinea impatiens growth response and nutrient release from controlled-release fertilizer in a recirculating subirrigation and top-watering system. HortScience 39:280-286.

Sakazaki, U. 2011. Heliotrope plant named 'USHTRP0303'. United States Patent Application. 18 Mar. 2018. <https://patents.google. com/patent/USPP21681P2/en>.

Starman, T. and L. Lombardini. 2006. Growth, gas exchange, and chlorophyll fluorescence of four ornamental herbaceous perennials during water deficit conditions. J. Amer. Soc. Hort. Sci. 131:469-475.

Starman, T.W., S.E. Beach, and K.L. Eixmann. 2007. Postharvest decline symptoms after simulated shipping and during shelf life of 21 cultivars of vegetative annuals. HortTechnology 17:544-551.

Taiz, L., E. Zeiger, I.M. Møller, and A. Murphy. 2015. Plant physiology and development. Sinauer Assoc., Inc., Sunderland, MA.

Wang, Q., J. Chen, R.H. Stamps, and Y. Li. 2005. Correlation of visual quality grading and SPAD reading of green-leaved foliage plants. J. Plant Nutr. 28:1215-1225.

Wright, R.D. 1986. The pour-through nutrient extraction procedure. HortScience 21:227229. 